\title{
Dentistry and otorhinolaryngology cooperative therapy of chronic maxillary sinusitis: Case series study
}

\author{
Han-Chang Yu' ${ }^{1}$ Pil-Young Yun ${ }^{1}$, Na-Hee Chang ${ }^{2}$, and Young-Kyun Kim ${ }^{1,3 *}$ \\ ${ }^{1}$ Department of Oral and Maxillofacial Surgery, Section of Dentistry, Seoul National University Bundang Hospital, Seongnam, Republic of Korea \\ ${ }^{2}$ Biomedical Research Institute, Seoul National University Bundang Hospital, Seongnam, Republic of Korea \\ ${ }^{3}$ Department of Dentistry and Dental Research Institute, School of Dentistry, Seoul National University, Seoul, Republic of Korea
}

For the maxillary sinus to normally function, the ventilation and drainage should be well maintained. The natural ostium of the maxillary sinus could be blocked owing to various reasons. In this condition, recurrence is likely to occur although the cause of maxillary sinusitis is treated. In this study, patients with chronic maxillary sinusitis were subjected to preoperative computed tomography. Overall, 11 patients with natural ostium obstruction and nasal septum deviation were examined and underwent otorhinolaryngological surgeries such as functional endoscopic sinus surgery and septoplasty. Of the 11 patients who exhibited complete healing after maxillary sinus treatment, 13 implants were placed in 5 patients. The average follow-up period was 5 years except for 2 patients who were lost to follow-up after prosthetic delivery or repeatedly exhibited failure for osseointegration. The success and survival rates of 9 of 11 patients were $100 \%$, with no marginal bone loss.

Key Words: Maxillary sinusitis, Otolaryngology

(c) This is an open-access article distributed under the terms of the Creative Commons Attribution Non-Commercial License (http://creativecommons.org/licenses/by-nc/4.0) which permits unrestricted noncommercial use, distribution, and reproduction in any medium, provided the original work is properly cited.

\section{서 론}

정상적인 상악동의 기능 유지를 위해서는 상악동 자연공 개 구부(natural ostium)가 잘 유지되어야 하고, 상악동 점막의 섬 모운동과 점액이 정상적으로 유지되어야 한다. 치성감염, 상악 동 골이식, 점막거상 시 천공 등으로 상악동 내의 감염이 발생할 수 있으나, 상악동 자연공이 막히지 않았다면 적절한 처치로 정 상적인 상악동 환경을 회복시킬 수 있다. 그러나 비중격 만곡이 나 상악동 자연공 개구부가 막히는 해부학적 이상소견이 있는 경우 정상적인 점액섬모운동이 저해 받게 되면 단순한 원인 제 거만으로 상악동염의 회복이 어려울 수 있으며 상악동염의 반
복적인 재발을 일으킬 수 있다. 이러한 만성 상악동염을 장기간 방치하게 될 경우 골수염으로 이행되거나 주변 부비동으로 감 염이 확산될 수 있기 때문에 시기 적절한 처치가 요구된다[1].

부비동 및 비강의 해부학적 변이는 약 $68 \%$ 에서 관찰되며[2], 상악동과 자연공 개구부의 몇몇 변이들은 부비동의 폐쇄에 기 여할 수 있다. 부비동개구연합(ostio-meatal unit)의 여러 해부 학적 변이(비중격만곡, 수포성갑개[concha bullosa], haller cell 등)가 있는 경우 상악동의 합병증 발병률이 더 높다고 보고하고 있으며[3-5], 이러한 경우 기능적 부비동 내시경수술(functional endoscopic sinus surgery, FESS)을 적용할 수 있다. FESS는 폐쇄된 자연공 개구부를 최소 침습적 수술로 개방하여 상악동

Received October 21, 2019; Revised November 14, 2019; Accepted November 18, 2019

${ }^{*}$ Corresponding author: Young-Kyun Kim, Department of Oral and Maxillofacial Surgery, Section of Dentistry, Seoul National University Bundang Hospital, 82 Gumi-ro, 173beon-gil, Bundang-gu, Seongnam 13620, Republic of Korea.

Tel: +82-31-787-7541, Fax: +82-31-787-4068, E-mail: kyk0505@snubh.org

Copyright $\odot 2019$, Oral Biology Research Institute 
의 환기와 배출을 회복시켜주는 술식이다[6]. 또한 상악동의 통 기성 외에도 정상적인 점액섬모운동 역시 환기와 배액에 있어 매우 중요한 역할을 담당하고 있다. 이에 저자들은 치과수술을 받은 환자들에서 만성 상악동염이 존재하는 경우 FESS 등의 상 악동의 환기를 개선시키는 이비인후과 수술을 시행한 후 만성 상악동염이 해소된 환자들에 대한 후향적 증례관찰연구를 시행 하였으며 치과-이비인후과 협진 치료의 중요성을 제시하고자 한다.

\section{대상 및 방법}

분당서울대학교병원 치과 구강악안면외과에 내원한 환자들 중 만성 상악동염이 존재하는 환자의 술 전 computed tomography (CT) 등의 검사에서 자연공 개구부 폐쇄소견, 비중격만 곡 등이 관찰된 남자 7 명, 여자 4 명의 총 11 명의 환자들을 조사 하였다. 환자들의 연령은 26세부터 86세로 평균 55.8세였다. 술 전 임상증상 및 방사선 소견, 치과관련 수술의 종류, 이비인후과 치료 방법 및 투약력, 이비인후과 치료 경과, 치료 후 임플란트 처치가 이루어진 환자의 경우 임플란트 생존 및 성공과 변연골 소실 등을 조사하였다.

임플란트 식립 후 초기고정(primary stability)과 이차수술 혹 은 인상채득 시 이차고정(secondary stability)은 Osstell mentor (Integration Diagnostics AB, Goteborg, Sweden)를 이용 해 측정된 것을 조사하였다. 6 명 중 4 명에게서 초기 안정도가 측정되었으며, 평균치는 62.45 임플란트 안정성 지수(implant stability quotient, ISQ)였다.

Table 1. Type of surgery performed

\begin{tabular}{lc}
\hline \multicolumn{1}{c}{ Surgery } & n \\
\hline FESS & 7 \\
Septoplasty & 1 \\
FESS+septoplasty & 2 \\
Marsupialization & 1 \\
Total & 11 \\
\hline
\end{tabular}

FESS: functional endoscopic sinus surgery.

Table 2. Type of antibiotic used

\begin{tabular}{lc}
\hline \multicolumn{1}{c}{ Antibiotic } & n \\
\hline Clarithromycin & 1 \\
Cefditoren & 3 \\
Moxifloxacin & 1 \\
Amoxicillin+clavulanic acid & 6 \\
Total & 11 \\
\hline
\end{tabular}

임플란트 식립 시, 보철물 장착 후, 보철물 장착 1 년 후, 최종 관찰시의 변연골 소실량을 파노라마 혹은 치근단방사선 사진을 이용하여 측정하였다. 식립된 임플란트의 길이를 참고하여 각 방사선 사진의 확대율을 계산한 후 근심측과 원심측에서의 변 연골 흡수량을 측정한 후 평균값을 구하였다.

임플란트의 성공은 Albrektsson 등[7]의 기준을 따라 유동성, 통증, 지각이상, 방사선 투과성 병소, 임플란트 주위염이 존재하 지 않으면서 진행성 골 흡수가 없는 경우(식립 1 년간 $1 \mathrm{~mm}$ 이 하, 이후 연간 $0.2 \mathrm{~mm}$ 이하)로 설정하였으며, 임플란트 생존의 기준은 식립 후 특별한 증상 없이 상부 보철물의 기능이 정상적 으로 이루어지고 있는 경우로 설정하였다.

\section{결 과}

11 명 중 자연공 개구부 폐쇄 소견을 보인 환자는 9명이었으 며, 이 중 5명은 비중격 만곡 소견도 함께 보였다. 모든 환자들 은 방사선 사진상 상악동의 방사선 불투과상과 상악동 점막 비 후가 관찰되었다. 11명 중 $\mathrm{FESS}$ 가 단독으로 시행된 환자는 7 명, septoplasty가 단독으로 시행된 환자는 1명, 2명은 FESS 와 septoplasty가 동시에 시행되었으며, 한 명은 septoplasty 와 marsupialization을 동시에 시행하였다. 대부분의 환자는 이비인후과 상악동 수술 후 amoxicillin/clavulanic acid 또는 cefditoren이 7일 투여되었다. 상악동 처치 후 질환 완치를 확인 한 11 명의 환자들 중 5 명에서 13 개의 임플란트가 식립되었으며 1 명에게 식립된 2개는 골유착이 반복적으로 실패하였다. 식립 한 5명 중 3명은 FESS만 시행하였고, 2명은 FESS와 septoplasty 를 동시에 시행한 환자였으며, 반복적으로 골유착이 실패한 환 자의 경우 FESS 시행 후 TS III (Osstem, Busan, Korea)임플란 트를 식립하였다. 보철완료 후 내원하지 않은 1 명의 1 개 임플란 트와 반복적으로 골유착이 실패한 2개의 임프란트를 제외한 나 머지 10 개의 평균 추적기간은 5년이며, 성공률, 생존율은 $100 \%$ 로 평균 골소실량은 $0 \mathrm{~mm}$ 였다. 위의 임플란트의 반복 실패로 현재 경과 관찰 중인 한 명을 제외하고는 모두 상악동 질환이 완 치되었음을 확인하였다(Table 1-3, Fig. 1, 2).

Table 3. Value of survival, success rate and marginal bone loss

\begin{tabular}{lc}
\hline \multicolumn{1}{c}{ Implant } & Value \\
\hline Success rate $(\%)$ & 100 \\
Survival rate $(\%)$ & 100 \\
Marginal bone loss $(\mathrm{mm})$ & 0 \\
\hline
\end{tabular}



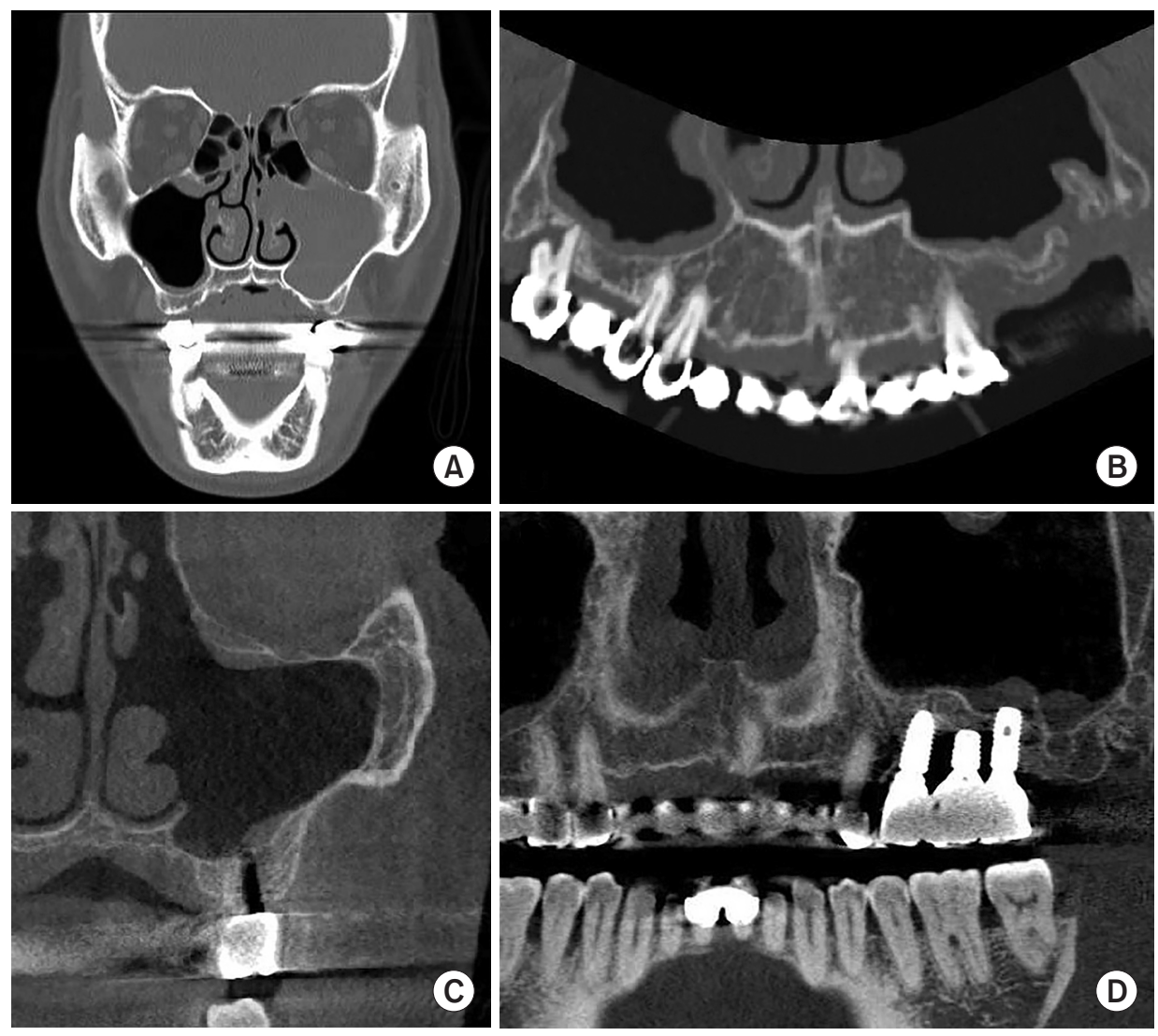

Fig. 1. (A) Cone beam computed tomography $(\mathrm{CBCT})$ of the first visit. Left maxillary sinusitis and obstruction of natural ostium can be observed. (B) Three months postoperative CBCT, the disappearance of maxillary sinusitis can be observed. (C) Four years and 3 months postoperative $\mathrm{CBCT}$, the patency of natural ostium is well maintained. (D) Six years and 3 months postoperative CBCT, it was confirmed that there was no particular problem of the maxillary sinus.
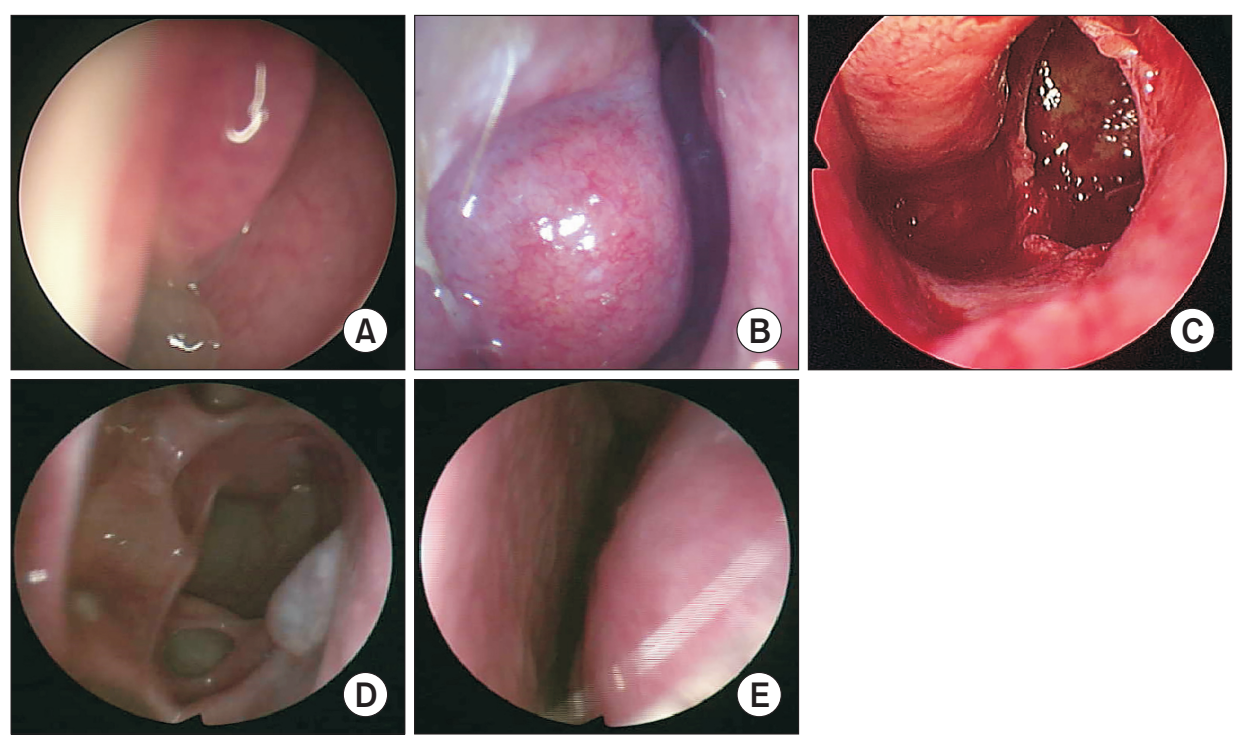

Fig. 2. (A, B) Endoscopy at first visit, thickening of the nasal mucosa and retention of mucus can be observed. (C) Endoscopy after functional endoscopic sinus surgery (FESS) surgery, natural ostium was expanded. (D, E) Endoscopy 1 year after FESS surgery, the natural ostium recovered well and the mucous membranes remained intact.

\section{고 찰}

상악동의 정상 기능을 유지하기 위해서는 자연공 개구부의 개방과 점액섬모 기능과 분비물의 생성이 정상적으로 이루어 져야 한다. 다양한 원인들에 의해 이들이 손상 받거나 폐쇄될
수 있으며, 이러한 경우 상악동염이 쉽게 발생할 수 있다. Timmenga 등[8]의 연구에 따르면 만성 상악동염의 원인은 술 후 초기에 병발한 상악동염이 완치되지 않았기 때문이라 하였다. Manor 등[9]은 술 전 상악동염 병력을 가진 환자들에서 수술 후 상악동염 재발이 빈번하게 발생한다고 언급하였다. Misch [10] 
은 수술 중의 상악동 내 오염이 상악동염 발생의 주 원인이라고 언급하였다. 또한 상악동 거상술 시행 시 자연공 근처까지 점막 을 거상한 경우 자연공 개구부를 막게 되어 상악동염이 발생되 는 경우도 있다[11]. 만성 상악동염의 병력이 있는 환자의 경우 $50 \%$ 에서 상악동 거상술 후 상악동염이 발생한다고 보고되어 있 으므로 상악동 수술 전 상악동염을 치료하는 것이 좋다[12]. 임 상가들은 상악 대구치 발치 혹은 소수술, 상악동골이식술, 상 악 구치부 임플란트 식립과 같이 상악동 점막에 자극을 주는 수 술들은 상악동 점막의 정상적인 생리반응의 손상을 유발하면서 합병증을 유발할 수 있다는 가능성을 생각하고 진료에 임해야 한다.

비중격(nasal cartilage)은 서골(vomer)과 만나는 부분에서 예각을 형성하면서 비중격 만곡을 일으키기도 한다[13]. 심한 비중격 만곡은 비강의 환기를 방해하여 상악동염을 발생시키는 원인으로 작용할 수 있으나, 2016년 Lee 등[3]의 보고에 따르면 상악동염과 비중격 만곡 사이에는 통계적으로 유의성이 없었으 나 자연공 개구부의 개통을 방해할 수 있는 haller cell의 유무는 상악동 거상술 후 상악동염의 발생과 통계적으로 유의한 결과 를 보였다. 이전 연구에 따르면 haller cell의 유병률은 $6 \%$ 에서 45.1\%로 다양하게 보고되고 있다[3,13].

상악동염은 원인에 따라 경구 항생제만으로 치료한 보고가 있고[14], 생리식염수를 사용해 비강점막을 씻어주는 것이 도움 이 된다는 보고 또한 있으나[8] 이러한 보존적 처치로 상황이 호 전되지 않는다면 적절한 수술적 접근이 권장된다.

상악동염의 발병 원인은 여러 가지가 있으나 치과에서 주로 처치하게 되는 것은 치성기원으로 발생한 상악동염이다. 여러 치료 방법이 있으나 그중 가장 중요한 것은 원인의 해결이다. 원 인치아의 처치가 상악동염을 해결하는 데 가장 중요하다. 하지 만 치성기원의 상악동염이라 하더라도 상악동이 정상적인 기능 을 유지하지 못한다면 근원치료가 완료되더라도 상악동염이 완 치되지 않을 수 있다. 상악동의 정상적인 기능이 유지되기 위해 서는 환기와 배출(ventilation and drainage)이 중요하며 이것 이 유지되기 위해서는 상악동의 자연공 개구부가 잘 개통되어 있어야 한다. FESS는 폐쇄된 자연공 개구부를 제한적인 수술 방 법으로 개방하여 상악동의 환기와 배출을 회복시키도록 하는 술식이다. 따라서 치성기원으로 발생하게 된 상악동염의 처치 전 상악동의 정상적인 기능이 유지될 수 있는 환경인지 CT 등 의 검사를 시행하여 상악동의 환기와 배출이 정상적으로 이루 어질 수 없는 상황이라면 이비인후과와 치과의 협진이 필요하 다. 본 연구에서 임플란트의 반복적인 실패를 보인 한 명의 환 자를 제외하고는 모두 이비인후과 수술 및 치과 치료 후 상악동 질환이 완치되었음을 확인하였다. 상악동염의 반복적인 재발이 발생한 환자는 이전에 식립하였던 \#26-27 임플란트가 골유착
에 실패하여 제거하면서 상악동 골이식을 동시에 시행하였다. 이후 감염 증상들과 구강상악동누공이 발생하여 약물치료를 통 해 증상이 소멸되었으며 8개월 후에 상악동골이식과 구강상악 동누공 폐쇄수술을 시행하였다. 4개월 뒤 \#25, 26 부위에 임플 란트를 다시 식립하였으나 6개월 후 좌측 코의 악취와 가래, 코 막힘 등의 증상 발현되었다. 그러나 임플란트 골유착 및 임플란 트 주변조직은 안정적인 상태를 보여 절개 배농술 시행 후 상악 동 세척 및 약물치료를 시행하였다. CT 검사상 자연공 개구부의 폐쇄소견이 관찰되어 이비인후과에 의뢰하였으며 전신마취하 에서 FESS를 시행하였다. 2년 후 \#25-26 임플란트 주위염에 대 한 치료를 시행하면서 식염수로 세정할 때 코로 넘어가는 증상 이 있었으며 피판을 거상한 결과 구강상악동누공이 다시 관찰 되었다. 소파술 3개월 후\#25-26 임플란트의 동요도 및 저작 시 통증이 관찰되어 임플란트를 제거하고 경과 관찰 중에 있다. 반 복적인 상악동염의 발생 원인으로는 1994년경 발생한 교통사 고로 인해 양측 상악동 전벽의 파손과 고정판이 잔존해 있고, 심 한 외상으로 인하여 상악동 내부의 상태가 불량하며 반흔성 조 직으로 인한 혈행장애가 있을 것으로 생각되며, 처음 실패한 임 플란트를 제거한 후 재식립한 임플란트들이 매우 가깝게 식립 됨으로 인해 구강 위생관리 불량 및 임플란트 주위염이 발생하 여 구강상악동누공이 다시 형성되면서 상악동염이 재발한 것으 로 추정된다. 또한 심장 및 신장질환이 있어 와파린을 복용하고 있는 환자로서 전신 면역기능이 저하되어 있을 가능성이 있으 며 비중격이 만곡되어 있는 것도 반복적 상악동염 재발에 기여 했을 가능성이 있다.

상악 구치부 임플란트 치료를 위해 내원한 환자들의 초진 시 반드시 CT를 촬영하여 상악동의 상태를 정확히 파악하고 상악 동 자연공 개구부의 폐쇄가 관찰될 경우나 상악동의 원활한 환 기와 배액에 영향을 미칠 것으로 생각되는 해부학적 구조물의 이상 소견들이 관찰된다면 이비인후과와 협진하여 적극적으로 처치하는 것이 상악동염의 재발을 방지하고 성공적인 상악동골 이식 및 임플란트 치료를 수행할 수 있다.

\section{CONFLICTS OF INTEREST}

The authors declare that they have no competing interests.

\section{ORCID}

\author{
Han-Chang Yu \\ https://orcid.org/0000-0001-9050-025X
}




\author{
Pil-Young Yun \\ https://orcid.org/0000-0001-6097-1229 \\ Na-Hee Chang \\ https://orcid.org/0000-0001-8634-571X \\ Young-Kyun Kim \\ https://orcid.org/0000-0002-7268-3870
}

\section{REFERENCES}

1. Huh S, Lee CY, Ohe JY, Lee JW, Choi BJ, Lee BS, Kwon YD. Chronic maxillary sinusitis and diabetes related maxillary osteonecrosis: a case report. J Korean Assoc Oral Maxillofac Surg 2015;41:332-337. doi: 10.5125/jkaoms.2015.41.6.332.

2. Bolger WE, Butzin CA, Parsons DS. Paranasal sinus bony anatomic variations and mucosal abnormalities: CT analysis for endoscopic sinus surgery. Laryngoscope 1991;101(1 Pt 1):56-64. doi: 10.1288/00005537-199101000-00010.

3. Lee JW, Yoo JY, Paek SJ, Park WJ, Choi EJ, Choi MG, Kwon $\mathrm{KH}$. Correlations between anatomic variations of maxillary sinus ostium and postoperative complication after sinus lifting. J Korean Assoc Oral Maxillofac Surg 2016;42:278283. doi: 10.5125/jkaoms.2016.42.5.278.

4. Parra M, Olate S, Cantín M. Clinical and biological analysis in graftless maxillary sinus lift. J Korean Assoc Oral Maxillofac Surg 2017;43:214-220. doi: 10.5125/jkaoms.2017.43.4.214.

5. Han JD, Cho SH, Jang KW, Kim SG, Kim JH, Kim BJ, Kim $\mathrm{CH}$. Lateral approach for maxillary sinus membrane elevation without bone materials in maxillary mucous retention cyst with immediate or delayed implant rehabilitation: case reports. J Korean Assoc Oral Maxillofac Surg 2017;43:276-
281. doi: 10.5125/jkaoms.2017.43.4.276.

6. Dhong HJ. Endoscopic sinus surgery: past, present, and future. J Clinical Otolaryngol 2011;22:141-153.

7. Albrektsson T, Zarb G, Worthington P, Eriksson AR. The long-term efficacy of currently used dental implants: a review and proposed criteria of success. Int J Oral Maxillofac Implants 1986;1:11-25.

8. Timmenga NM, Raghoebar GM, van Weissenbruch R, Vissink A. Maxillary sinusitis after augmentation of the maxillary sinus floor: a report of 2 cases. J Oral Maxillofac Surg 2001;59:200-204. doi: 10.1053/joms.2001.20494.

9. Manor Y, Mardinger O, Bietlitum I, Nashef A, Nissan J, Chaushu G. Late signs and symptoms of maxillary sinusitis after sinus augmentation. Oral Surg Oral Med Oral Pathol Oral Radiol Endod 2010;110:e1-e4. doi: 10.1016/ j.tripleo.2010.02.038.

10. Misch CE. Maxillary sinus augmentation for endosteal implants: organized alternative treatment plans. Int J Oral Implantol 1987;4:49-58.

11. Smiler DG, Johnson PW, Lozada JL, Misch C, Rosenlicht JL, Tatum OH Jr, Wagner JR. Sinus lift grafts and endosseous implants. Treatment of the atrophic posterior maxilla. Dent Clin North Am 1992;36:151-186; discussion 187-188.

12. Tidwell JK, Blijdorp PA, Stoelinga PJ, Brouns JB, Hinderks F. Composite grafting of the maxillary sinus for placement of endosteal implants. A preliminary report of 48 patients. Int J Oral Maxillofac Surg 1992;21:204-209. doi: 10.1016/ s0901-5027(05)80219-x.

13. Arslan H, Aydinlioğlu A, Bozkurt M, Egeli E. Anatomic variations of the paranasal sinuses: CT examination for endoscopic sinus surgery. Auris Nasus Larynx 1999;26:39-48. doi: 10.1016/s0385-8146(98)00024-8.

14. Small SA, Zinner ID, Panno FV, Shapiro HJ, Stein JI. Augmenting the maxillary sinus for implants: report of 27 patients. Int J Oral Maxillofac Implants 1993;8:523-528. 